\title{
Dallen J. Timothy (ed.) (2016), Heritage Cuisines: Traditions, Identities and Tourism, London and New York, Routledge ${ }^{1}$
}

\author{
Recensão de Iolanda Ramos \\ Universidade Nova de Lisboa-FCSH/CETAPS
}

O volume editado por Dallen J. Timothy integra a colecção "Routledge Studies of Gastronomy, Food and Drink". Apresenta uma perspectiva inter/multidisciplinar sobre os desafios que se colocam à indústria alimentar e destina-se não só a investigadores e académicos mas também a leitores que se interessem por gastronomia e estudos sobre a alimentação, assim como por turismo, hospitalidade, lazer, gestão hoteleira, estudos culturais, antropologia, sociologia, geografia e marketing. Dallen J. Timothy é professor na área de Community Resources and Development na Universidade do Arizona e editor do Journal of Heritage Tourism, tendo como principais áreas de investigação o património cultural, o impacto do turismo e o desenvolvimento sustentável, os processos de globalização e o supranacionalismo, a par da biodiversidade e das dinâmicas das regiões periféricas.

Em Heritage Cuisines. Traditions, Identities and Tourism, a alimentação é abordada como sendo um dos mais importantes elementos culturais e um factor representativo da identidade regional e étnica, para além de reflectir o interesse crescente nas tendências da alimentação como fazendo parte do desenvolvimento económico e social. Embora existam muitos estudos sobre hábitos alimentares e modos de confeccionar os alimentos na óptica da hospitalidade, gastronomia, agronomia e cadeia alimentar de oferta-procura, a obra 
pretende colmatar o que considera ser uma lacuna na investigação sobre a diversidade da alimentação como património cultural e respectivos contextos e características. Para tal, visa examinar práticas gastronómicas, tradições intergeracionais, agricultura sustentável, rituais indígenas e histórias de migração/emigração/imigração. De entre outros aspectos relacionados com a alimentação e os hábitos alimentares como património cultural, este estudo destaca elementos como folclore, religião, língua, laços familiares, estruturas sociais, determinismo ambiental, celebrações e cerimónias, paisagens, rotas culinárias, odores e sabores.

A obra, de 195 páginas, segue uma abordagem temática nos 13 capítulos incluindo a introdução e a conclusão - que a compõem e cujos títulos correspondem às reflexões dos respectivos autores sobre tradições, identidades diaspóricas, colonialismo, nacionalismo, nostalgia, agriturismo, religião, mercados, marketing, festivais gastronómicos e slow food. No final de cada capítulo, o leitor encontra não só informações pertinentes, mas também problemáticas sustentadas por um bom aparato teórico e respectivas referências bibliográficas. É de salientar igualmente a existência de um paratexto muito apelativo, complementando a curiosidade do público-leitor por meio de ilustrações e tabelas. Nessa medida, é possível visualizar insectos cozinhados, que passaram de alimentação de camponeses a especialidade culinária, bem como imagens de mercados, restaurantes, livros de receitas, letreiros indicativos de rotas de alimentação e anúncios publicitários a festivais gastronómicos. Quanto às tabelas, incluem informações bastante úteis, nomeadamente, uma lista de designações protegidas pela Comissão Europeia e que integra, a título de exemplo, o queijo Feta da Grécia e o Roquefort de França (registados na classe de produtos como queijo), a Pizza Napoletana de Itália (na classe de produtos de confeitaria, pão e massas) e as ostras Whitstable do Reino Unido (na classe de produtos de peixe fresco, moluscos e crustáceos). A estes dados acrescem exemplos de museus de património culinário, uma tipologia de mercados no contexto patrimonial e os resultados de uma pesquisa sobre slow food e temas afins, levada a cabo entre 1980 e 2015.

A argumentação apresentada ao longo do volume é consistente com os objectivos delineados e esclarece o leitor sobre a importância de democratizar o acesso às 
gastronomias locais e nacionais, incentivando a diversidade à escala global. Com efeito, a alimentação, tomada como património cultural, reflecte as regras e valores de diferentes pessoas, locais e épocas, promovendo o conhecimento e o contacto com outras sociedades e civilizações. Os autores constatam que existem, contudo, muitas narrativas ainda latentes e muitas histórias por contar no âmbito da preservação de memórias, identidades e tradições num mundo crescentemente tecnológico.

Se, como guardiã do passado e repositório de cultura, a alimentação constitui "a veritable archive of information about evolving human relations and forces of nature" (Timothy 2016: 180), ela é também responsável por uma perspectiva crítica do património cultural que merece ser explorada. Nessa medida, ganha relevo a sugestão de se estudar, sob uma perspectiva comparatista, o legado gastronómico de diferentes potências coloniais (Portugal, Grã-Bretanha, França, Países Baixos, Itália) nos territórios colonizados.

Tendo presente um propósito de articulação entre os Estudos sobre a Alimentação e os Estudos sobre a Utopia, é de notar que se encontra na introdução do volume editado por Timothy uma reflexão sobre o cariz político que pode ser conferido ao património, tanto material como imaterial, de modo a manipular quer os cidadãos nacionais, quer os turistas: "History can be retold or rewritten to convince visitors of the utopian values of a society or to extol its many virtues" (idem: 2-3). Assim sendo, o património pode ser utilizado para contar uma versão da História que nunca existiu.

Por último, importa acrescentar que este texto, como muitos outros no âmbito dos Estudos sobre a Alimentação, traz à tona a dificuldade de tradução para português da terminologia a utilizar, visto que ainda é comum manter-se, na linguagem corrente, expressões em língua inglesa. Encontram-se, neste caso, designações como slow food e fast food. Dúvidas de ordem tradutória colocam-se, desde logo, no próprio vocábulo "food", passível de ser traduzido tanto por "comida" como por "alimento" e "alimentação", bem como, por exemplo, em expressões como food movements e foodways, aqui entendidos, de acordo com o usual, como "tendências da alimentação" e "hábitos alimentares". Contudo, diversos vocábulos revelam-se complexos num contexto de tradução. É o caso de cuisine quando confrontado com culinary, visto que a terminologia permite a utilização de 
"cozinha" e "culinária" como sinónimos ou, por empréstimo linguístico, a manutenção em português do vocábulo inglês. 0 mesmo se pode dizer sobre gourmet tourists, "turistas gourmet", ficando em aberto para matéria de debate se existe em português uma designação para o turismo culinário que evite a conotação negativa de "turistas viciados em comida" e que possa transmitir devidamente o gosto pelas experiências culinárias e o conhecimento de diferentes pratos nacionais, aliado à curiosidade sobre o processo de cultivo e de produção dos alimentos, contido nas expressões foodies e foodie tourists.

Subjacente a estas questões, e incontornável face à temática desenvolvida em Heritage Cuisines. Traditions, Identities and Tourism, cabe salientar o desafio linguístico que diz respeito à palavra heritage e com o qual o leitor se depara de imediato no título da obra. Sendo "património" a tradução mais adequada em termos gerais, seria também possível optar por "herança" e "legado", a fim de cobrir o campo semântico que em língua inglesa é expresso tanto por heritage como por patrimony. Na verdade, esta distinção surge logo no índice, no tocante à conclusão, cujo subtítulo explicita "Heritage cuisines and the patrimony of food". Conclui-se deste modo que, para além da sua relevância conceptual, a obra em análise contribui igualmente para incentivar o debate em torno de uma terminologia cuja tradução para língua portuguesa continua a alimentar dúvidas e questões.

\section{NOTA}

${ }^{1} 0$ presente trabalho foi realizado no âmbito do Projeto ALIMENTOPIA / Utopian Foodways, financiado por Fundos FEDER através do Programa Operacional Competitividade e Internacionalização - COMPETE 2020 e por Fundos Nacionais através da FCT - Fundação para a Ciência e a Tecnologia (PTDC/CPC-ELT/5676/2014 | POCI-01-0145-FEDER-016680). 